\title{
La conservació-restauració del Castellot de Bolvir. La interdisciplinarietat de l'arqueologia
}

\author{
Delia Eguiluz Maestroํㅜ, Alba Morell Hom²
}

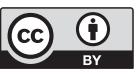

Rebut: $25 / 05 / 2020$

Acceptat: 29/11/2020

\section{Resum}

El treball interdisciplinar és, avui en dia, un element plenament integrat dins de qualsevol recerca arqueològica. I dins d'aquesta gran disciplina ens trobem amb un dels elements més importants i indispensables com és la conservació-restauració, ja que garanteix tant la preservació de tot el conjunt de béns que ens arriben del passat, com permet el seu estudi i difusió. En aquest sentit, aquest article es centra en l'anàlisi dels diferents tipus d'intervencions de conservació i restauració que durant anys han ajudat a que el jaciment d'El Castellot de Bolvir (Girona) sigui un referent arqueològic a la Cerdanya.

Paraules clau: conservació; restauració; arqueologia; ciència; patrimoni; interdisciplinarietat; pluridisciplinarietat; sitja

\section{Abstract. The archaeological conservation in Castellot de Bolvir: Interdisciplinarity in archaeology}

Interdisciplinary work is currently a fully integrated element in any archaeological investigation. Within this large discipline, conservation is one of the most important and indispensable specialties. It guarantees not only the preservation of our historical heritage, but also allows its study and cultural promotion. This article focuses on the analysis of the different conservation interventions that, for years, have helped make the site of El Castellot de Bolvir (Girona) an archaeological landmark in Cerdanya.

Keywords: conservation; restoration; archaeology; science; heritage; interdisciplinary; pluridisciplinary; silo

Eguiluz Maestro, Delia; Morell Hom, Alba. «La conservació-restauració del Castellot de Bolvir. La interdisciplinarietat de l'arqueologia». Treballs d'Arqueologia, 2020, núm. 24, p. 245-261. DOI: $10.5565 / \mathrm{rev} / \mathrm{tda} .116$

1. Restauradora-conservadora de béns arqueològics i paleontològics freelance. delia.eguima@gmail.com

2. Restauradora-conservadora de béns arqueològics a Arqueòlegs.cat. albamoho@gmail.com 


\section{El Castellot de Bolvir}

Les primeres intervencions arqueològiques al jaciment de El Castellot de Bolvir (Girona) van iniciar-se a l'any $1990 \mathrm{i}$ han continuat fins a l'actualitat. Durant aquests anys s'han documentat diverses fases d'ocupació. La primera, del bronze final-primera edat del ferro que, a causa de les poques restes conservades, és la més desconeguda. La segona ocupació pertany a l'època ceretana (segle IV a II a.n.e.), moment en què es va crear un petit oppidum rodejat per una muralla i un fossat defensiu. D'aquest oppidum podem destacar la presència d'un gran camp de sitges conservades a intramurs i un conjunt d'àmbits domèstics adossats amb bateria a la muralla ibèrica. L'arribada romana dins dels territoris ceretans al segle II a.n.e. va provocar canvis socials, territorials i econòmics. El Castellot va patir una nova transformació dins de les seves estructures, ja que es va realitzar un reforç defen- siu de certa importància, construint diverses torres quadrangulars, un cos de guàrdia i una nova entrada monumental. A més a més, part de les estructures habitacionals ceretanes van ser modificades per adequar-se a les noves necessitats de l'assentament. Un exemple va ser la creació d'un possible espai de producció metal-lúrgic on es van conservar restes de diverses llars de foc de manipulació del metall amb materials utilitaris per aquest tipus de manufactures com gresols ceràmics. A finals del s. I ane, aquest oppidum es va abandonar de forma pacífica en el context de la fundació de Iulia Libica dins de la nova estructuració territorial romana (Morera, 2017).

Per últim, ens trobem amb una quarta fase que data d'època medieval, que aniria des del segle $\mathrm{x}$ fins al XII. El turó va ser reforçat de nou amb la construcció d'una muralla que va rodejar tot el perímetre i es van crear nous espais habitacionals, tots ells realitzats amb la tècnica de

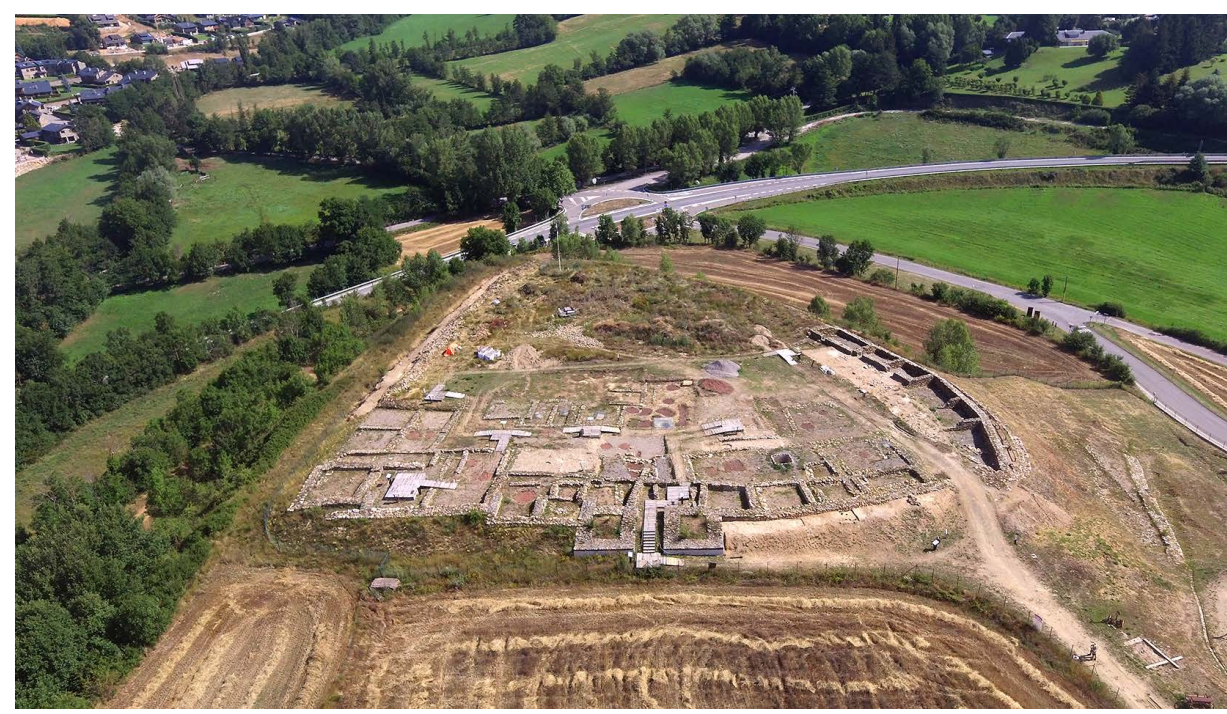

Figura 1. Vista general del jaciment de El Castellot de Bolvir (Cerdanya). Font: Arqueòlegs.cat 
opus spicatum. Per acabar, s'ha de destacar que en aquest moment es van construir sistemes de drenatge amb canals de desguàs situats al llarg de la muralla (Olesti et al., 2018: 133-145).

L'estudi de tot aquest context històric i material va generar la necessitat de formar un equip multi i interdisciplinari que reunís professionals pertanyents a àmbits com la història, l'arqueologia, la conservació-restauració, la ceramologia, la palinologia, la geologia, etc. Un equip que no només treballa de forma independent dins de les seves especialitats sinó que durant anys, ha aconseguit crear una xarxa de col.laboració que ha estat fonamental a l'hora de desenvolupar l'estudi arqueològic i històric d'aquest jaciment tan complex com el Castellot.

En relació amb la conservació-restauració de béns arqueològics, no és nova la idea de la responsabilitat que s'ha de tenir a l'hora de tractar i preservar tot el patrimoni que es troba a les diferents campanyes arqueològiques, tant si són béns mobles com immobles. En aquest sentit, El Castellot sempre ha comptat amb la presència d'un rellevant nombre de conservadores-restauradores que, des de les primeres campanyes, s'han encarregat de garantir la conservació de tots els béns i ajudar a la seva comprensió i difusió.

\section{La conservació-restauració a El Castellot de Bolvir. Consideracions prèvies}

La realització dels treballs de conservació i restauració estan es troben sota uns criteris i protocols d'intervenció bàsics. Aquestes intervencions s'apliquen seguint les directrius de la normativa vigent. Cal comentar que, la carta d'Atenes de 1930 fou el primer document internacional que va fer referència a la conservació i restauració del patrimoni. Amb els anys, però, la restauració i la conservació s'ha anat professionalitzant $\mathrm{i}$, per tant, hi ha hagut diverses renovacions de mètodes, lleis i criteris per un afí en comú amb l'objectiu d'obtenir la màxima preservació i conservació de patrimoni històric i cultural.

Actualment, es prioritzen els següents criteris bàsics:

- L’aplicació del criteri de la mínima intervenció, és a dir, manipular i actuar sobre els béns el menys possible per tal d'evitar intervencions excessives e innecessàries que, fins i tot, puguin arribar a generar situacions irreversibles, o, en el cas de les reintegracions, crear falsos històrics. Així doncs, totes les actuacions s'han de centrar a obtenir una major estabilització, consolidació i protecció dels béns tractats, per tal de garantir la seva perdurabilitat i estabilitat en el temps (ICOMOS, 2000).

- Totes les estructures, espais i béns tractats han d'estar exhaustivament documentats i identificats abans i després de la intervenció (ICOMOS, 1964).

- S'ha de prioritzar, sempre que sigui possible i no comprometi la integritat del bé, garantir la màxima reversibilitat de tots els materials utilitzats, ja que s'ha de tenir present en tot moment, la possibilitat que, en el futur, es pugui realitzar qualsevol mena de nova intervenció.

- A més a més, aquests materials no només han de ser reversibles sinó que també, en la mesura del possible, inerts, estables i sostenibles amb el medi ambient (ICOMOS, 2000). 
- Les zones on es realitzen reintegracions, aquestes han de ser òpticament diferenciades per tal d'evitar confusions mimètiques o falsificacions (ICOMOS, 1964).

Com s'ha esmentat anteriorment, aquests criteris es regeixen tant per lleis nacionals com internacionals.

\section{L'estudi dels factors d'alteració extrínsecs: formació geològica i característiques mediambientals del jaciment}

A l'hora de determinar les alteracions que pateixen els materials arqueològics resulta imprescindible conèixer, d'una banda, les característiques fisicoquímiques del sòl en el qual han estat enterrats i, d'altra banda, les característiques climàtiques de l'entorn, per a així comprendre quins han estat els seus agents i factors extrínsecs de degradació.

El jaciment de El Castellot està situat en una terrassa anomenada la Corona, al sud-est del municipi de Bolvir. Presenta una superfície d'uns $6000 \mathrm{~m}^{2}$ (Morera, 2017: 179) i a una alçada aproximada de $1.265 \mathrm{msnm}$. Es tracta d'una zona on els sòls estan constituïts per acumulacions de dipòsits sedimentaris formats principalment per graves, sorres, llims i argiles que presenten una permeabilitat mitjana. ${ }^{3} \mathrm{La}$ tendència a l'acidesa del sòl (a causa de la presència de matèria orgànica procedent de la descomposició de la vegetació) és compensada pel component argilós que, com ja hem vist, forma part del conjunt litogràfic del sòl. Per tant, el pH resultant és neutre.

Si analitzem les condicions climàtiques d'aquesta zona, es pot determinar que es caracteritzen per la manifestació constant de grans oscil-lacions tèrmiques i de canvis d'humitat durant tot el dia i totes les estacions de l'any. A més a més, la neu està present durant els hiverns (amb unes mínimes de $-12{ }^{\circ} \mathrm{C}$ ) i, durant els estius, es poden arribar a registrar temperatures màximes d'uns $30^{\circ} \mathrm{C}$ amb precipitacions puntuals de gran intensitat (Morera, 2017: 15).

Així doncs, dins d'aquest medi edàfic i tenint en compte les condicions ambientals que l'envolten, podem determinar que ens trobem davant de sòls rics en minerals amb una important presència d'humitat que, a més a més, varia de forma constant. Aquestes característiques que conformen l'entorn de El Castellot són, dins de l'estudi de la conservació dels restes arqueològics, un dels principals factors a tenir en compte a l'hora de determinar les alteracions i l'estat de conservació dels béns. ${ }^{4}$

\section{Els béns mobles}

Els béns mobles trobats al jaciment de El Castellot són principalment objectes manufacturats d'ús quotidià, tant d'època ceretana i romana com d'època medieval. Estan realitzats amb materials d'origen inorgànic com ceràmica, metall (bronze, ferro i or) i, en menor quantitat, vidre i

3. Dades extretes dels mapes litoestratigràfics i de permeabilitat del Instituto Geológico y Minero de España.

4. Tenint en compte que també els factors intrínsecs d'aquests objectes arqueològics afectaran a l'estat de conservació tant per composició material i tècniques productives (en cas de materials mobles manufacturats) com per composició mineralògica en el cas de les estructures pètries. 
pedra. ${ }^{5}$ Dins del context defensiu en què es desenvolupa l'assentament en certs moments de la seva història, es van exhumar també algunes peces de caràcter bèllic rellevants com puntes de llança o virolles. En definitiva, es tracta d'un conjunt de béns que donen evidències de com era la vida i com s'estructurava la societat en cadascuna de les fases d'ocupació i, per tant, la seva preservació i estabilització es converteix en una necessitat que no s'ha de passar per alt. En aquest sentit, la comunicació entre l'arqueòleg i el restaurador és fonamental, ja que junts poden establir quines són les peces susceptibles de ser estudiades o exposades $i$, d'elles, quines necessiten ser intervingudes.

\subsection{L'estudi dels materials $i$ les seves alteracions}

El grup de béns més abundant trobats a El Castellot i present a totes les fases d'ocupació, és el ceràmic. De manera molt general es pot afirmar, que es tracten majoritàriament de peces de producció local a torn $\mathrm{i}$ a mà amb coccions de tipus reductores. En alguns casos també s'han exhumat recipients d'importació com càlats decorats o gerres bicòniques (Olesti et al., 2018: 138).

Si atenem al seu estat de conservació, resulta molt habitual que aquestes restes es trobin molt fracturades a excepció d'alguns casos on els objectes s'han preservat complets. Un exemple, són els petits gresols, càlats o algunes olles de datació medieval. Gràcies a la neutralitat del $\mathrm{pH}$ del sòl i a la no excessiva presència de sals so- lubles, tant les pastes ceràmiques com les decoracions pintades solen manifestar un bon estat de conservació. No obstant això, de vegades ens trobem amb pastes ceràmiques molt febles $\mathrm{i}$ amb molta tendència a la descohesió. Degradacions causades, en part, per la mala manufactura d'aquestes peces i la baixa, però sempre present, acció salina del sòl.

Per altra banda, si ens centrem en els objectes d'origen metàl-lic, es pot determinar que són el grup més destacat de El Castellot, sobretot en les fases romana i medieval. Es tracta de peces realitzades majoritàriament en ferro forjat $\mathrm{i}$ bronze (com monedes, puntes de llança, sivelles, un simpulum, un esperó o eines d'ús quotidià com ganivets, navalles, etc.) i, de forma molt puntual, d'or, com va ser el cas d'una arracada naviforme, feta amb làmines d'or i sense presentar decoració, pertanyent a la fase republicana del jaciment (Olesti, 2018: 140).

Tant els objectes de ferro com de bronze, s'exhumen en un estat de deteriorament bastant avançat a causa de l'acció corrosiva de les sals presents en el subsol (entre elles, importants concentracions d'ions de clorur) i a la constant presència d'oxigen i humitat. A més a més, resulta també habitual trobar-se amb certes acumulacions de sorres, petites roques i altres minerals concrecionats a les capes superficials de corrosió d'aquestes peces.

En el cas del bronze ens trobem amb objectes molt complets (sivelles, monedes, didals, etc.), en un estat de deteriorament no molt avançat i amb formació, en molts casos de pàtines naturals. Així

5. En el cas dels materials d'origen orgànic, no s'ha trobat cap mostra, exceptuant restes òssies d'animals, exhumats fonamentalment a sitges reutilitzades com escombraries. Els nivells d'humitat i de matèria orgànica presents als sòls, fan que no sigui possible la conservació d'altres tipus de materials orgànics com teixits, cistelleria, etc. 


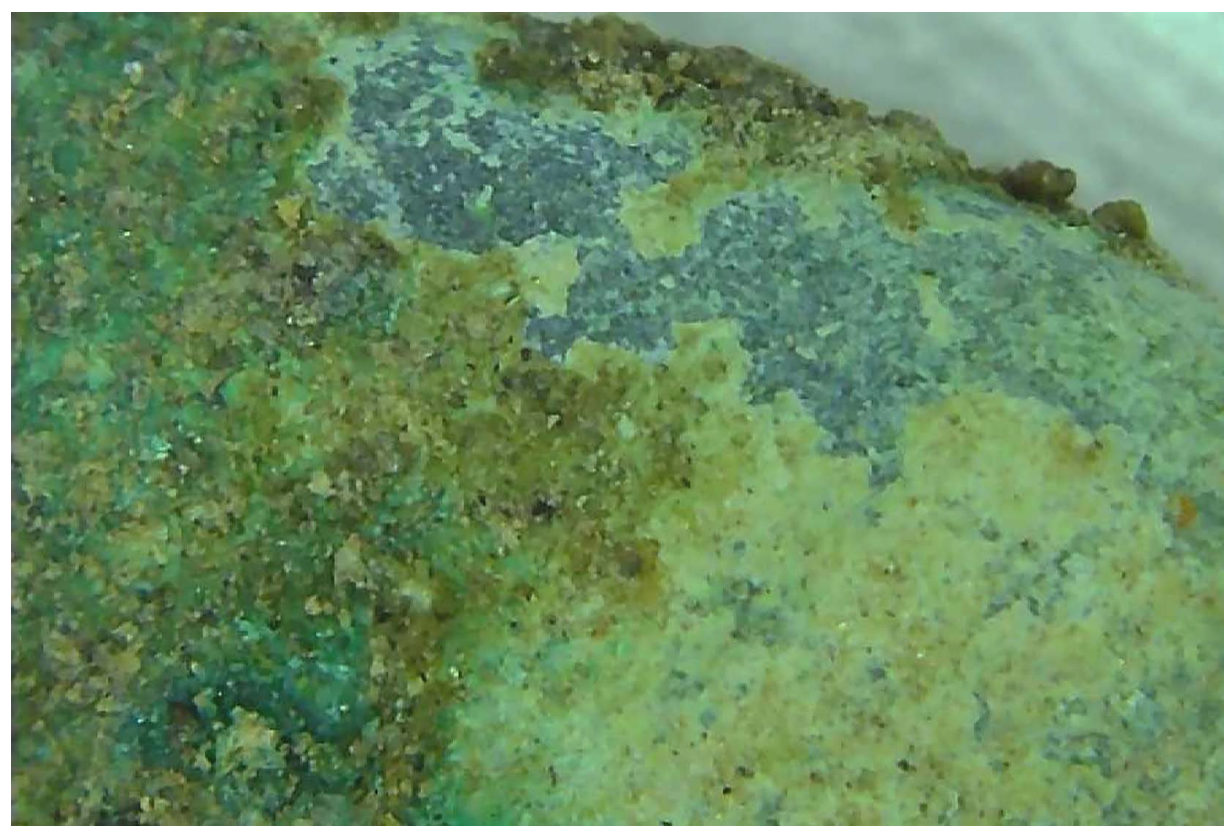

Figura 2. Imatge amb llapis òptic digital dels productes de corrosió que manifesta una peça de bronze de El Castellot, on es poden observar la presència de clorurs actius, brutícia superficial i certes restes de pàtina natural.

doncs, és habitual detectar la presència d'òxids de coure, punts de clorurs actius (principalment d'atacamita) i zones amb concrecions molt carbonatades i adherides a la superfície. Dins d'aquest context, l'ús del llapis òptic digital pot convertir-se en una eina molt útil a l'hora d'ajudar a determinar els diferents productes de corrosió i altres tipus de patologies no visibles a simple vista. ${ }^{6}$ Per l'estudi del bronze, facilita la detecció de punts de corrosió activa, petites fissures o laminacions i zones amb pàtines naturals no facilment detectables.

Centrant-nos en l'altre gran grup metàl.lic que es troba en El Castellot, és a dir, el ferro, hem de dir que es tracten d'objectes molt destacats quant al seu interès històric-científic. Així doncs, podem esmentar peces destacades com puntes de llança i virolles, anells o ganivets.

Els principals productes de corrosió que ens trobem en els objectes de ferro són òxids de ferro com la magnetita o l'hematites i oxids de ferro hidratats com la limonita o la goethita, la qual es manifesta en les capes més superficials de la peça. Tots ells són productes de corrosió molt habituals, dels quals es pot destacar la goethita i la magnetita com aquells productes de corrosió que han permès la preservació d'aquests objectes gràcies a les

6. Resulta important destacar que sempre s'intenten utilitzar, en la mesura del possible, mètodes d'anàlisi no destructius per sobre d'aquells en els que es necessiten mostres dels originals. 


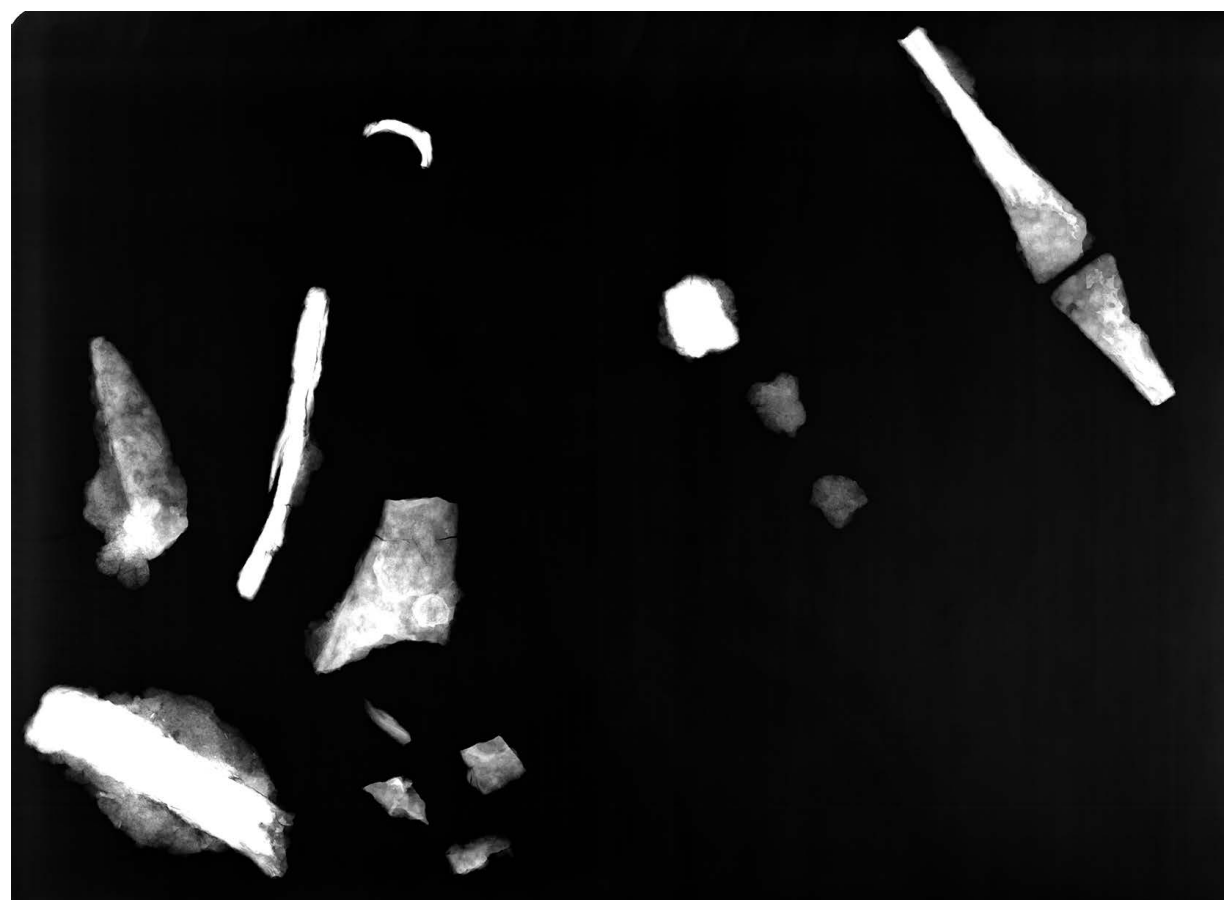

Figura 3. Imatge generada per raigs $\mathrm{X}$ on es pot observar el grau de mineralització de diversos objectes de ferro extrets de El Castellot i la presència o absència de nucli metàl-lic.

seves propietats estabilitzadores i protectores (Jegdic, 2012). D’altra banda, aquells que es troben en un estat més delicat de conservació, manifesten importants concentracions de limonita en zones principalment interlaminars. Així doncs, ens trobem amb peces de ferro relativament estables, però molt alterades, amb greus fissures i deformacions (butllofes, laminacions, etc.) produïdes per productes de corrosió que en alguns casos han portat, fins i tot, a la pèrdua completa del nucli metàl-lic de la peça.

Com s'ha esmentat anteriorment, la realització d'analítiques pot ser una eina clau a l'hora d'obtenir una millor caracterització dels objectes metàl-lics i del seu estat de mineralització. En el cas de El
Castellot, es duen a terme proves de Raigs $\mathrm{X}$ en aquelles peces de ferro rellevants on la capa de corrosió cobreix de tal manera la superfície metàl-lica que no és possible observar si existeixen decoracions o algun altre element singular a tenir en compte. Així doncs, aquesta anàlisi ajuda a decidir quin tipus de tractament aplicar i ajuda a prevenir possibles neteges inadequades sigui per ser excessives o per ser massa cauteloses.

\subsection{Tipus d'intervenció. Del camp al museu}

En molts casos quan algú fa una representació mental d'un restaurador es té la visió d'una persona amb bata dintre d'un 
laboratori o taller, treballant amb molta cura i concentració. Efectivament, aquesta imatge és absolutament real si només entenem com restauració aquesta fase. En realitat, el treball del conservador-restaurador va molt més enllà i, en el cas del món arqueològic, s'inicia juntament amb l'excavació arqueològica i acaba en el moment en què les peces es col-loquen dins d'una vitrina del museu o a les caixes d'emmagatzematge.

En aquest sentit, El Castellot és un exemple d'aquesta pràctica, ja que el restaurador és un dels professionals que formen part de cadascuna de les intervencions arqueològiques que es realitzen cada any. La seva presència en el camp ajuda a millorar la manipulació inicial de tots els béns mobles que s'extreuen per, així, reduir possibles danys que el canvi tan dràstic d'ambient els hi pot generar. ${ }^{7}$ A més a més, també s'encarrega de les extraccions de les peces que es troben en un estat més delicat de conservació i requereixen una primera intervenció de consolidació en el mateix jaciment.

Una vegada les peces han arribat al laboratori, s'inicien els estudis analítics d'estat de conservació i es decideixen quins seran els tractaments més adients en funció, per una banda, de les condicions de deteriorament que manifesten els objectes i, per l'altra, dels objectius estètics i científics que es volen aconseguir. De nou, ens trobem amb la importància de mantenir una bona comunicació amb arqueòlegs i especialistes per tal d'establir uns interessos comuns, però garan- tint, en tot moment, la cura envers el bé patrimonial.

Tots els tractaments que es realitzen als béns mobles de El Castellot tenen com a objectiu principal retornar l'estabilitat dels materials constituents per, així, frenar o reduir el seu deteriorament. No obstant això, també es consideren les necessitats dels especialistes a l'hora de realitzar els seus estudis o l'aplicació de certa intenció artística, per tal d'ajudar a la comprensió d'aquells objectes que són exposats.

En el cas de les peces d'origen ceràmic, totes les intervencions se centren en la reconstrucció d'aquelles que conserven la major part del seu material constitutiu original o presenten una gran rellevància $o$ interès científic (com poden ser, per exemple, restes de peces amb decoració pintada). En aquest cas, les intervencions s'inicien amb la dessalinització de les pastes $i$ la seva neteja superficial. Aquelles que ho necessiten són reconstruïdes utilitzant adhesius reversibles fets a base de resines sintètiques. En el cas que la peça ho requereixi (normalment per motius de reforç o per millorar la seva lectura), també es realitzen reconstruccions puntuals. Aquestes reintegracions són fixes o extraïbles i estan realitzades amb guix i pigments naturals o acrílics aplicats amb aerògraf.

Per altra banda, les intervencions que es realitzen a les peces de bronze es basen en neteges mecàniques que tenen com $\mathrm{a}$ objectiu eliminar clorurs i carbonats utilitzant neteges puntuals químiques com l'ús de dissolucions de EDTA o amb el

7. És sabut que, durant el seu període d'enterrament, tots els materials que conformen els béns arqueològics tendeixen a establir un equilibri físic i químic amb el medi ambient en el qual es troben (Gómez, 2008: 147-150). Així doncs, la seva extracció i consegüent manipulació, que comporta un canvi radical en les seves condicions mediambientals, pot implicar conseqüències de deterioració irreversibles per a aquests objectes (Pugès i Fernández, 2012: 14). És per això que el treball d'un restaurador ha de centrar-se a pal.liar els efectes de degradació que es puguin ocasionar. 

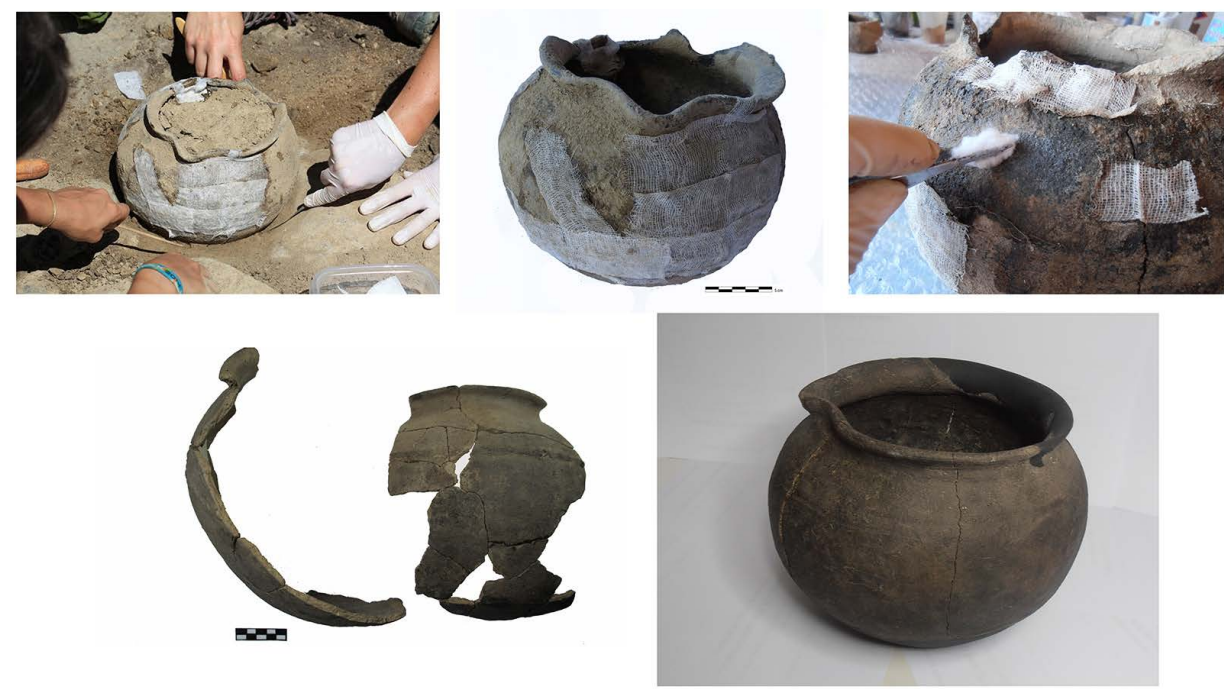

Figura 4. Exemple del procés d'intervenció d'una olla medieval des de la seva extracció al camp fins a la seva exposició.

mètode Rosemberg per a aquells objectes amb presència de punts molt concrets de clorurs actius. ${ }^{8}$ L'assecatge és un dels punts més importants dins del conjunt d'intervencions en metalls (no només en bronze, també pel ferro o qualsevol altre aliatge) i, en el cas del Castellot, se solen utilitzar els banys en dissolvents com l'etanol o l'acetona.

Com a inhibidor s'utilitza BTA, un inhibidor orgànic que forma una pellícula molt prima que retarda el procés de corrosió del metall. Per crear una barrera de protecció aïllant d'agents d'alteració com l'oxigen o la humitat, s'utilitza una resina acrílica $\left(\right.$ Paraloid $^{\circledR}$ B-44) aplicada a baixa concentració.
Per últim, per aquells objectes de ferro que són tractats, les intervencions se centren, com en el cas dels de bronze, en neteges mecàniques molt suaus i controlades. Aquestes neteges tenen la intenció d'eliminar tots els productes de corrosió que resulten no òptims per a l'estabilitat del metall conservat o d'aquells que deformen o cobreixen l'objecte de manera que impedeix estudiar la seva morfologia original. Les eines que es van utilitzar van ser el bisturí, el llapis de fibra de vidre i el microtorn (que només es fa servir per retirar les concrecions més resistents). Els clorurs que es troben presents en aquestes peces i que són uns dels agents de corrosió més perillosos pels ferros arqueològics, són eli-

8. Resulta important aclarir que l'elecció d'una neteja química només respon a una necessitat pròpia de la peça davant les seves característiques, el seu estat de deteriorament i el tipus de corrosió activa que presenti. Aquesta elecció és decisió final del restaurador professional encarregat de la intervenció i sempre ha d'estar justificada i ha de respondre al criteri bàsic de mínima intervenció donant prioritat a l'estabilitat del material constitutiu. 

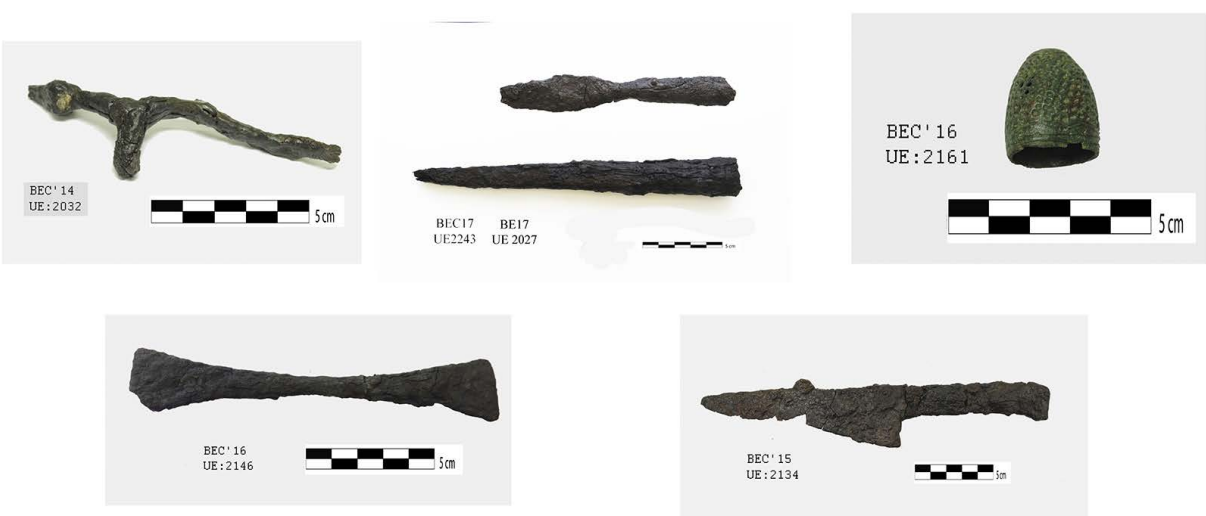

Figura 5. Conjunt de peces metàl.liques procedents del jaciment de El Castellot després de la seva intervenció.

minats mitjançant neteges químiques de $\mathrm{NaOH}$. Aquesta dissolució alcalina genera la difusió dels ions de clorur presents al ferro cap a la pròpia dissolució. Tot i que no és una neteja completament eficient, sí que ajuda a disminuir les concentracions de clorurs als ferros i, per tant, el risc de corrosió. (Tordera, 2016: 38). Per a l'estabilització del ferro s'utilitza l'àcid tànnic a una baixa concentració i es protegeix amb una capa de resina acrílica final.

En el cas de ser necessari algun tipus d'adhesió, es realitza amb resines epoxídiques tenint sempre en compte que han de ser reversibles i sempre de marques que garanteixin la màxima efectivitat.

\subsection{La conservació preventiva}

Dins de la disciplina de la conservaciórestauració es troba la conservació de caràcter preventiu. Aquesta constitueix, de manera indiscutible, el conjunt d'intervencions més importants que cal portar a terme per tal d'evitar el deteriorament de qualsevol objecte arqueològic una vegada ha estat exhumat $\mathrm{i}$ intervingut.
El Museu Espai Ceretània, situat al vessant del jaciment del Castellot, s'ha convertit en el centre d'emmagatzematge de tot el material que s'ha extret durant les excavacions i també en el principal espai d'exposició d'aquelles peces més rellevants. És per això, que es tracta d'una tasca fonamental centrar-se en totes aquelles activitats encaminades a la seva conservació preventiva. Aquestes són principalment de dos tipus. Per una banda, les relacionades amb els materials d'emmagatzematge, els quals responen a tots els requisits que s'exigeixen per garantir l'estabilitat dels materials dels objectes (inerts, de $\mathrm{pH}$ neutre, lliures d'àcids i molt estables davant possibles canvis mediambientals), com caixes de tancament hermètic, escumes de polietilè, etc. Per altra banda, aquelles que se centren a controlar l'estat ambiental dins de la sala d'exposició, com la revisió periòdica de totes les peces exposades o la col-locació de llums LED, sense càrrega tèrmica, termòmetres, indicadors d'humitat i gels de sílice lliures de clorur de cobalt dins de les vitrines. L'objectiu de tot plegat és evitar els canvis 

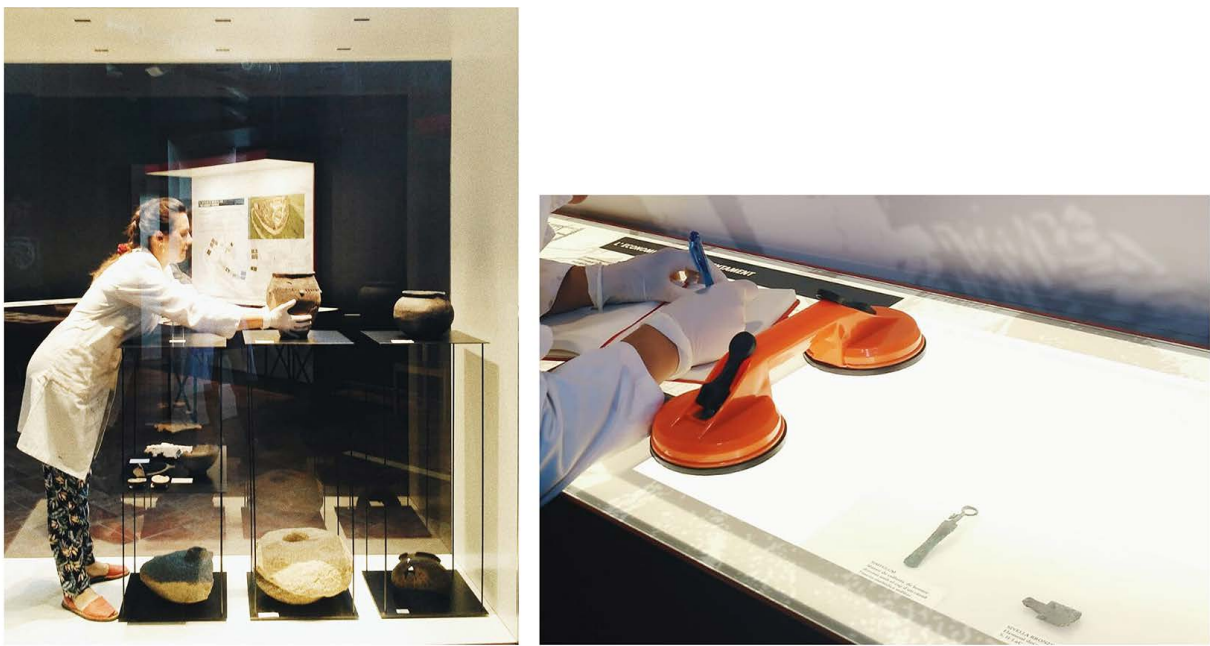

Figura 6. Sistema d'embalatge i exposició dels objectes intervinguts a l'Espai Ceretània.

bruscos en la temperatura i la humitat relativa per tal de frenar els processos de degradació que poden desenvolupar-se en aquestes peces, sobretot a les peces d'origen metàl.lic.

\section{Béns immobles}

Fins al 2008 les actuacions d'excavació no afectaren plenament a les estructures, ja que es basaven en la seva documentació superficial i en la realització de sondeigs puntuals; així, un cop acabada la intervenció corresponent, l'espai excavat es cobria amb una capa de geotèxtil fixada amb pedres i terra. Però el fet d'esgotar l'estratigrafia d'un ampli sector del jaciment i deixar les estructures d'aquesta zona uns 50-60 cm per sobre de la superfície, va causar un nou replantejament de la direcció del projecte arqueològic i es van començar les intervencions de consolidació $\mathrm{i}$ restauració. Per això, es van establir els primers criteris i directrius sobre la conso- lidació d'estructures exhumades (murs, sitges, llars, etc.) i, també, l'adequació general del jaciment per fer-lo visitable. Des de llavors, i fins a l'actualitat, s'ha procedit als treballs de consolidació a pràcticament la totalitat de les estructures excavades.

Cal comentar que no tan sols s'han dut a terme actuacions de consolidació, sinó també de conservació preventiva com, per exemple, la col-locació de tubs de PVC a l'interior de les habitacions de llevant, on es van afegir uns desguassos soterrats i dirigits cap a l'exterior dels límits del jaciment. La intenció d'aquesta intervenció va ser la d'evitar l'estancament constant d'aigües pluvials, ja que aquestes havien provocat una important degradació perimetral a les estructures després de la seva exhumació. També es van portar a terme altres actuacions, com el recobriment de les sitges, que, una vegada exhaurit el sediment antròpic, es van reomplir amb terres netes i graves, per tal de frenar qualsevol mena de despreniment de les seves parets originals. Per úl- 
tim, també s'ha d'esmentar l'afegit de cobertes de vidre de protecció de petites estructures (com en el cas de quatre fogars que es van restaurar in situ), que garanteixen que els factors climatològics no afecten directament a la superfície d'aquestes estructures.

\subsection{L'estudi de les estructures $i$ les seves alteracions}

Abans de realitzar qualsevol intervenció s'ha de tenir en compte la tècnica constructiva de cada estructura. En termes generals, en el cas d'El Castellot, hi ha tres tipologies diferents, les quals estan relacionades amb les tres principals fases d'ocupació. A les construccions iberes, hi predominen còdols de gran format recolzats un sobre de l'altre en sec. En el cas de les construccions romanes, s'alternen els còdols amb pissarres $\mathrm{i}$, de vegades, algunes d'aquestes estructures tan sols són de pissarra. Finalment, en època medieval, les seves estructures són realitzades mitjançant el sistema constructiu d'opus spicatum. Aquestes darreres són les que mostren una millor conservació.

A causa de l'acció dels agents descrits anteriorment, les estructures pateixen un seguit d'alteracions que, si no existís una restauració i un control regular, podrien arribar a provocar la seva pèrdua o desaparició. És per aquest motiu que, en el moment del procés de consolidació, es prioritzen les estructures que mostren un pitjor estat de preservació i, en moltes ocasions, quan es manifesta un greu risc de deteriorament irreversible, es realitzen les denominades «intervencions d'urgència».

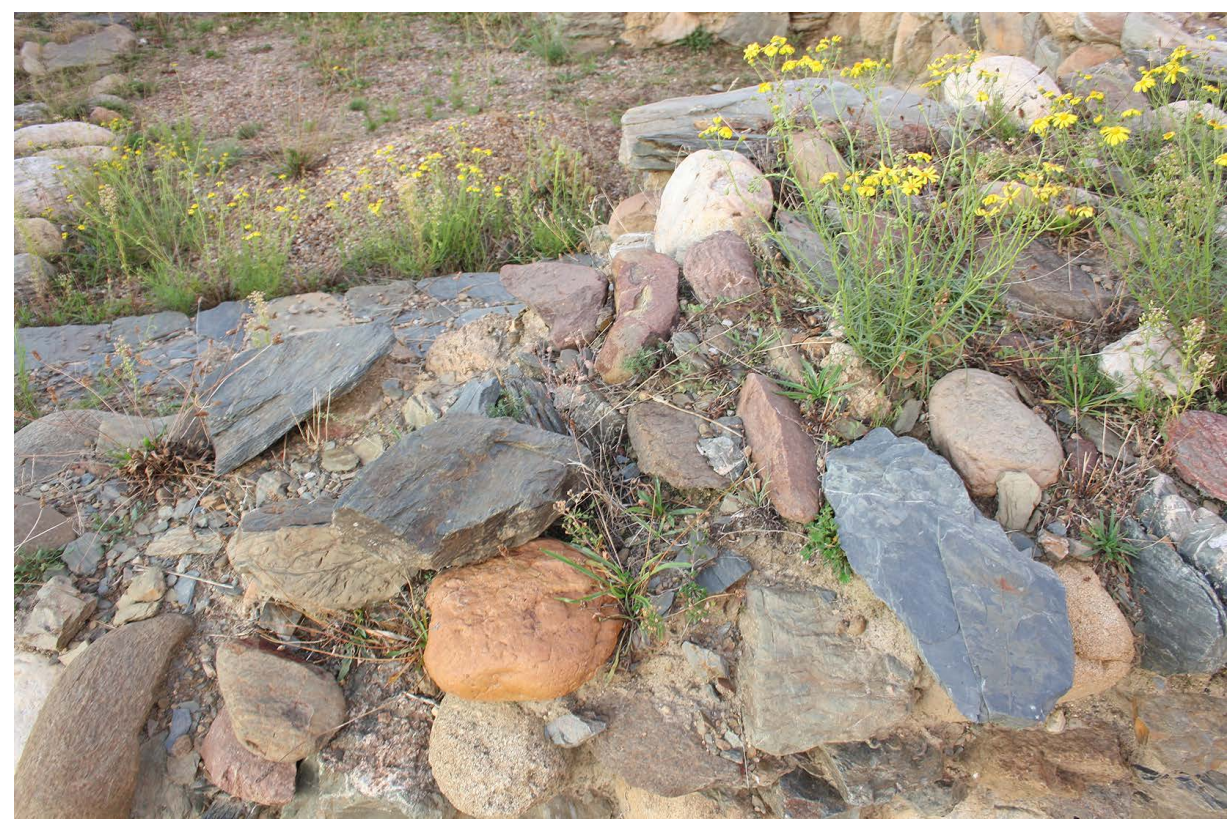

Figura 7. Alteracions del mur medieval UE 342 d'El Castellot causades pels agents biològics, provocant moviments i pèrdua d'elements estructurals. 
La pèrdua de suport i el moviment d'elements estructurals són les alteracions principals que trobem al Castellot. Aquestes són causades, fonamentalment, pels agents climatològics o agents biològics. Els agents climatològics provoquen un desgast a la part superior de les estructures i debiliten la cohesió dels elements constructius. El creixement dels agents biològics, com plantes superiors i inferiors, provoca que les arrels que s'han format a l'interior de les estructures causin moviments o, fins i tot, el seu enderrocament.

Existeix també una altra alteració que es manifesta de manera puntual i què, a la vegada, resulta molt perjudicial per a les estructures. Aquesta és la pèrdua de suport a les parts inferiors dels murs, el que provoca el minvament dels fonaments que garanteixen la seva estabilitat. Aquest fet és causat per l'acció antròpica dels treballs arqueològics, ja que, de vegades, existeixen estrats arqueològics anteriors a les estructures, fet que provoca la debilitació dels fonaments del murs. En aquests casos, es prioritza actuar ràpidament per evitar futurs enderrocs.

\subsection{Tipus d'intervencions i objectius}

Seguint els criteris bàsics d'actuació, com s'ha comentat prèviament, abans de realitzar qualsevol intervenció es redacta un estudi del deteriorament i de les alteracions que mostra el bé immoble a tractar $\mathrm{i}$, en base a aquestes dades, es decideix quina serà la intervenció més idònia. En el cas d'El Castellot, són diverses les intervencions que es porten a terme en funció dels tipus d'alteració que es detecten.

La principal intervenció que es realitza per a consolidar les estructures exhumades és la col-locació d'una capa de sacrifici sobre l'última filera conservada.
D'aquesta manera, els murs queden protegits de l'acció climatològica i biològica, fent que el principal impacte repercuteixi sobre aquesta capa i, com diu la seva denominació, se sacrifiqui en primer lloc. Per evitar discordances estètiques, s'utilitza la mateixa tècnica constructiva dels murs originals i es col-loca, entre l'última filera i la capa de sacrifici, una malla de plàstic que separa els afegits de l'original.

Per una altra banda, quan els béns immobles es troben a l'aire lliure, l'acció dels factors d'alteració són pràcticament inevitables; per tant, les consolidacions i reintegracions (capes de sacrifici, reintegracions matèriques, etc.) realitzades fa almenys una dècada han complert, fins al dia d'avui, la seva funció, però amb el pas del temps han acabat per degradar-se. És per aquest motiu que cal fer, de manera freqüent, un sanejament de totes aquelles antigues intervencions perquè així tornin a ser funcionals. De fet, algunes d'aquestes antigues restauracions es van realitzar amb materials no idonis que, fins i tot, han provocat l'acceleració del deteriorament del bé original.

De la mateixa manera, per obtenir una bona llegibilitat i comprensió del jaciment, a vegades és necessària la realització de reintegracions matèriques i volumètriques per acabar de definir certes estructures molt degradades i donar unitat al conjunt immoble. Resulta fonamental afegir que totes les reintegracions comporten un estudi i diàleg previ entre arqueòlegs i restauradores.

Finalment, a les zones que encara no han estat mai intervingudes, de vegades succeeixen certs enderrocs a causa de la pèrdua de la terra que actua com aglutinant i que genera la descohesió de les pedres. En cas d'absència, es realitza una reintegració matèrica i volumètrica, se- 


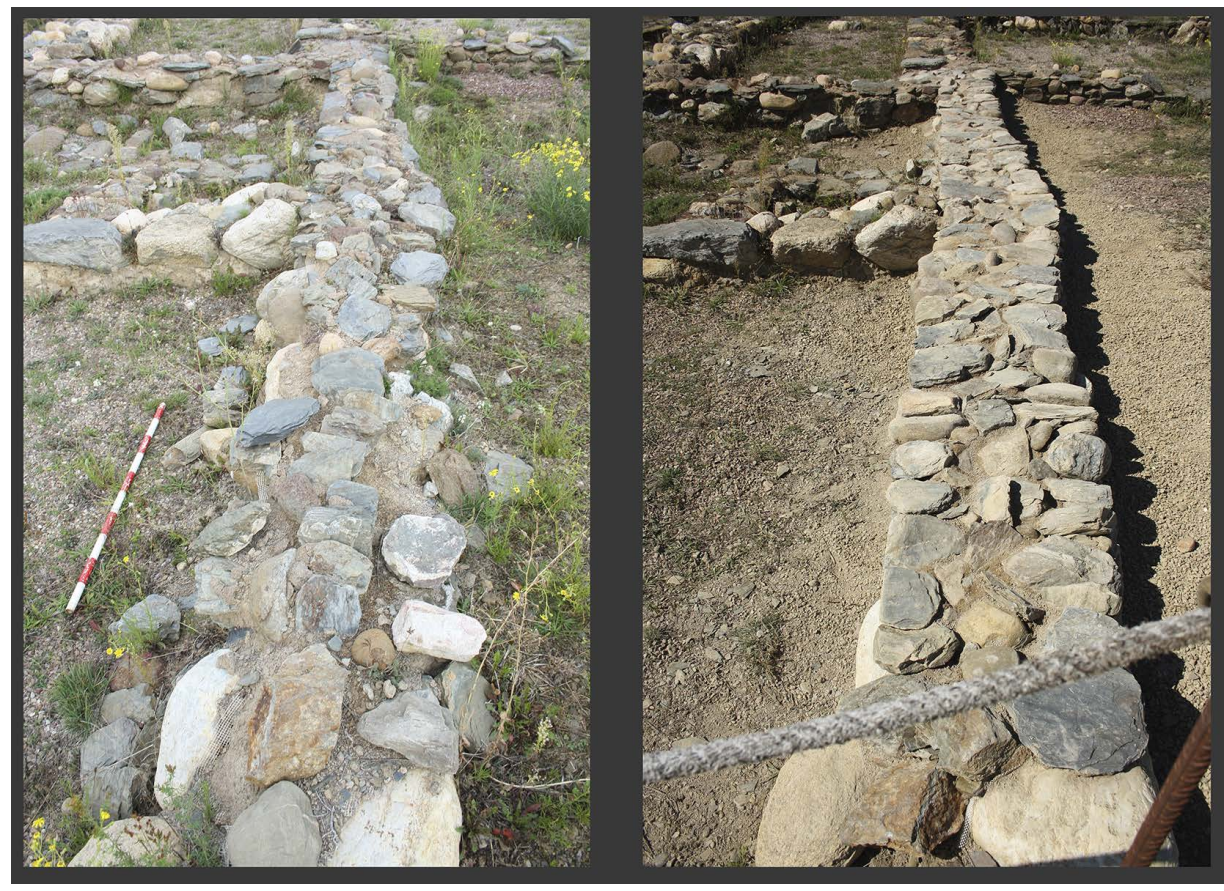

Figura 8. Mur republicà UE 33. Abans i després de la restauració i adequació de l'espai.

guint la mateixa tècnica arquitectònica i utilitzant una malla de plàstic com separador. Per altra banda, en cas de caiguda de pedres, aquestes es recol-loquen en el seu lloc original. S'ha de destacar que, dins d'aquest procés, la documentació fotogràfica i documental és fonamental per garantir la fidelitat de l'original.

Abans de realitzar qualsevol mena d'intervenció es realitza una neteja exhaustiva de les estructures per retirar les plantes superiors i les seves arrels i tota la terra afegida del període d'enterrament, assegurant la seva total eliminació. Cal comentar que, tot i que les estructures originals no tenen cap mena de morter de base cal, les consolidacions i reintegracions es fan amb un morter de calç hidràulica i àrid silici per, així, reforçar aquestes estructures davant de l'impacte directe dels fenòmens meteorològics i provocar un retrocés del creixement d'elements biològics.

\subsection{Intervenció d'una sitja iberoromana de parets terroses}

Durant la campanya de restauració i consolidació del 2018 es va actuar a l'interior d'una sitja iberoromana. Es tracta d'una sitja subterrània retallada directament al sòl, on les seves parets són el mateix sediment geològic a excepció d'un petit mur realitzat amb còdols de pedra que actuava de separació amb la sitja contigua. L'interès científic i museogràfic d'aquests elements que mostren com era la vida quotidiana va fer que es considerés la possibilitat 
de realitzar una intervenció de consolidació de les parts de terra per tal de poder deixar la sitja oberta al públic i frenar el seu deteriorament.

Val a dir que l'inici de les intervencions de consolidació i restauració es van complicar a causa d'unes precipitacions molt intenses. Aquestes precipitacions van inundar la sitja uns $30 \mathrm{~cm}$ i van generar un cert desgast de les parets i l'enderroc del mur de còdols. Així doncs, després d'evacuar l'aigua acumulada i d'analitzar el nou estat de conservació de la sitja, es va optar per realitzar una consolidació de les parets de terra, per reconstruir el mur construït a l'interior i per col-locar uns sistemes de protecció i drenatge per evitar futures inundacions.

Primerament, es va realitzar una consolidació i una reintegració matèrica de la paret de pedra construïda amb còdols de petit format, seguint el patró original. Seguidament, es va intervenir la resta de la sitja. Per la consolidació de les parets de terra, es decidí crear un cos ferm per assegurar l'adhesió del morter amb la terra. Aquest cos es va construir amb una malla metàl-lica que cobria tota les parets de l'interior. Posteriorment, es va afegir la primera capa de morter de calç i sorra a les parets. A la segona i tercera capa de morter es va afegir palla semi-triturada, un material plenament orgànic i reversible. La palla va aportar al morter una bona elasticitat i consistència, el que resultà essencial per la correcta adaptació de la massa a les irregularitats de la paret original. Una vegada finalitzada la consolidació de l'interior de la sitja i la consolidació del mateix mur, es van realitzar un

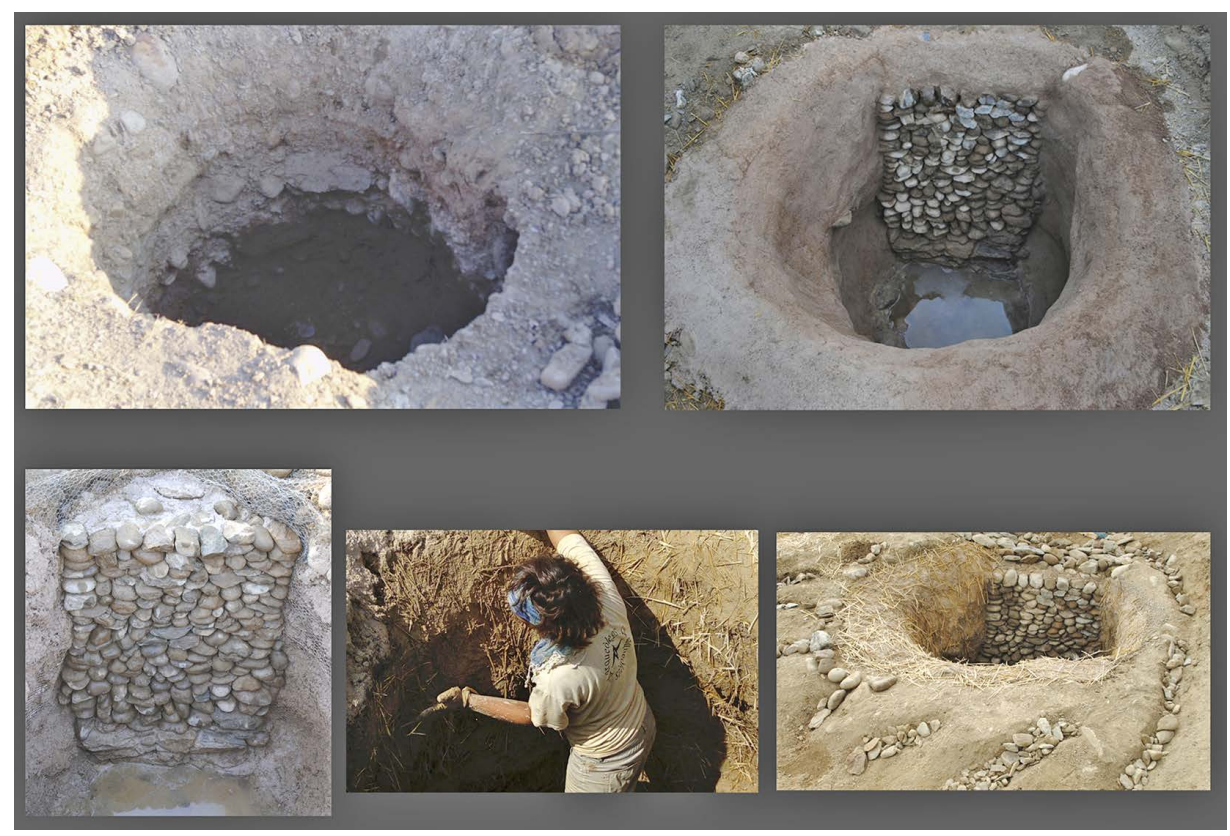

Figura 9. Abans, durant i després de la consolidació de la sitja iberoromana. Conjunt d'imatges que recull tot el procés de consolidació i adequació divulgativa de la sitja iberoromana. 
seguit de drenatges naturals (amb pedres de diferents grandàries) al voltant de la mateixa sitja, per evitar futures inundacions a seu interior.

Durant el procés de consolidació es va observar que part de l'aigua de l'interior de la sitja no tan sols era de les pluges externes, sinó que també procedia de filtracions provinents del subsol. És per aquest motiu que es va optar per no cobrir amb morter el fons de la sitja, per tal de permetre l'entrada i sortida de les filtracions sense alterar el circuit natural de l'aigua. Finalment, per evitar un impacte directe dels agents d'alteració, es va optar per la col-locació d'un vidre a la part superior de la sitja, a $20 \mathrm{~cm}$ d'alçada, perquè el bé respirés i es reduïssin les condensacions.

Cal comentar que no tenim constància a Catalunya de cap altra intervenció similar en sitges, de tal manera que no es disposà de cap mena de referència sobre una consolidació d'aquestes característiques. És probable, doncs, que estiguem davant d'una de les primeres intervencions de consolidació d'una sitja construïda directament al sòl en l'àmbit català. En aquest sentit, cal destacar que, després de dos anys, els resultats han estat molt positius i no ha calgut cap altra intervenció o reparació.

\section{Conclusions}

L'objectiu principal dels processos de restauració i conservació de béns mobles i immobles del Castellot de Bolvir es basa en la preservació, conservació, estabilització i perdurabilitat de cada una de les peces o monuments excavats. Així com permetre una major visibilitat i llegibilitat de tots els elements per facilitar una major difusió patrimonial.

Cal recordar que, tant pels béns mobles com immobles, la conservació preventiva és primordial si el que volem és garantir la seva estabilitat al llarg termini. En el cas dels béns immobles, com que no es pot evitar la seva interacció amb factors com el medi ambient o l'acció biològica d'animals i plantes, és necessari, almenys, un control anual per tal de frenar al màxim possible el seu natural deteriorament.

Per acabar, resulta fonamental ressaltar que totes les intervencions de conservació-restauració realitzades al Castellot de Bolvir han estat possibles gràcies a la formació d'un equip multidisciplinar composat per arqueòlegs, conservadors-restauradors, historiadors i diferents especialistes de l'àmbit de la ciència arqueològica, on cada professional dóna la seva part per obtenir un objectiu comú: la investigació i preservació del nostre patrimoni.

\section{Referències bibliogràfiques}

Antelo, T.; Bueso, M.; Gabaldón, A.; Costea, A. M. (2011). La técnica radiográfica en los metales históricos. Madrid: Ministerio de Cultura.

Carta de Cracovia (2000). Principis per la conservació i restauració del patrimoni construït. Cracòvia: ICOMOS. 
Carta de Lausana (1990). Assemblea general de ICOMOS. Lausana: ICOMOS.

CARTA DE Venècia (1964). II congrés internacional d'arquitectes i tècnics de monuments històrics. Venècia: ICOMOS.

España, T.; Montiel, V.; López-Segura, M.; Aldaz, A. (1985). «Limpieza y restauración electroquímica de objetos arqueológicos metálicos». Lucentum, 4, 185-190. <https://doi.org/10.14198/LVCENTVM1985.4.12>

García Fortes, S.; Flos Travieso, N. (2008). Conservación y restauración de bienes arqueológicos. Madrid: Patrimonio Cultural.

Gharib, A.; Mohamed, H.; Abdel Ghany, N. (2018). «Nondestructive techniques in the study of a gilded metallic sword from the islamic art museum». EJARS, 8, 15-21. <https://doi.org/10.21608/ejars.2018.9953>

Gómez, M. L. (2008). La restauración. Exámen científico aplicado a la conservación de obras de arte. Madrid: Ediciones Cátedra.

Guixeras, M. (2010). «Perquè la calç: quina, quan i com». Unicum, 9, 133-141.

Jegdić, B.; Polić-radovanović, S.; Ristic, S.; Alil, A. (2012). "Corrosion stability of corrosions products on an archaeological iron artefact». International Journal of Conservation Science, 3, 247-248.

Ley Orgánica 16/1985, de 25 de junio, del Patrimonio Histórico Español. BOE no 156, de 29 de junio.

Ley Orgánica 16/1985, de 25 de junio, del Patrimonio Histórico Español. BOE no 155, 18-19, de 29 de junio.

Morera, J. (2017). Territori i poblament de Cerdanya a l'Antiguitat: la iberització i romanització de la Vall Cerdana. Tesi doctoral inèdita. Barcelona: Universitat Autònoma de Barcelona.

Olesti, O.; Morera, J.; Oller, J.; Mercadal, O. (2018). «Paisatge i territori a la Cerdanya antiga: novetats arqueològiques al Castellot de Bolvir i al Tossal de Baltarga». Tribuna d'Arqueologia, 2015-2016, 132-156.

Pasíes Oviedo, T. (2005). «Los trabajos de conservación y restauración del material metálico del "Solar de la morería" (Sagunto)». ARSE, 39, 57-62.

Proyecto Coremans (2015). Criterios de intervención en materiales metálicos. Madrid: Ministerio de Cultura.

Pugès i Dorca, M. (2014). «La restauració del material arqueològic exposat al Born Centre Cultural». Unicum, 13, 39-53.

Pugès i Dorca, M.; Fernández Berengué, L. (2012). La conservación preventiva durante la exposición de materiales arqueológicos. Gijón: Trea.

Tordera Pérez, T. (2016). Estudio de la efectividad del ácido tánico sobre piezas de hierro arqueológico. Valencia: Universitat Politècnica de Valencia. 
